\title{
Reducing Corruption through Enhancing Public Service Ethics in Bangladesh
}

\author{
Fakhrul Islam \\ Assistant Professor \\ Dept. of Public Administration \\ Shahjalal University of Science \& Technology \\ Sylhet, Bangladesh \\ E-mail: fakhrul.bs11@gmail.com \\ Anindyta Deb Ananya (Corresponding Author) \\ Research Student \\ Dept. of Public Administration \\ Shahjalal University of Science \& Technology \\ Sylhet, Bangladesh \\ E-mail: anindytasust@gmail.com
}

Received: November 23, 2015 Accepted: December 17, 2015 Published: December 27, 2015

doi:10.5296/ijssr.v4i1.8418

URL: http://dx.doi.org/10.5296/ijssr.v4i1.8418

\begin{abstract}
Corruption exists within and between government organizations as the form of bribing, swindling, favoritism and many other forms which destroys the public morale. It spreads its greedy clutches all over the country; Government officials are engaged in corruption for greed for power, selfishness, wealth and money. This paper is an attempt to identify the forms of corruption in civil service and how ethical code of behavior to reduce the level of malfunctions. Social survey method has been followed for this study where the factor has been explained to know the perception of general people. The study finds that lack of accountability and transparency, dishonesty, nepotism and favoritism are also responsible for corruption and made suggestions to combat corruption in Bangladesh based on the perception of civil servants and the general people.
\end{abstract}


Keywords: corruption, public service, ethics, people's perception

\section{Introduction}

Corruption is a very famous word in a negative way. The familiar definition of corruption is defined by the World Bank and Transparency International (TI) as "the misuse of public office for private gain (Note 1). Another definition of corruption is existence of opportunity or power to use deliberately for personal or parochial gain. Patterns of corruption vary from society to society and over time which invariably channels public resources to the rich-the poor lack the funds to bribe or pay for the private provision of services that are supposed to be provided for free as public services. Individual perspectives associated with corruption can be divided into three more specific categories of perspectives. The first category is the individual or actor perspective (Elazar, 1972:93-102; Burrell \& Morgen, 1988:1-35). According to the Heidenheimer (1978:19-23), as well as Tilman (1968:440), corruption can be seen as a civil servants self-interest seeking behavior, which is associate with particulars of their job, such as the level of power they have, or the nature of the task they are performing. The second category of perspectives is the cultural perspective (Tobin \& Lee, 2012). Collier (2002) stressed the importance of political culture when attempting to understand corruption; they classify political culture into collectivist, individualistic, and egalitarian categories. Third category of perspectives is that institutional factors perspective (Myrdal, 1968:951-958; Heywood, 1997:11). So Patterns of corruption vary from different perspectives. Corruption distorts resource allocation and government performance because corrupted public servants, lacking a service mentality, become more interested in serving themselves than serving the public. Corruption always creates obstacles on the way of eradicating poverty and economic growth. It is usually known that almost all kinds of corruption perpetuate in politics and administration in Bangladesh. The most common form of corruption is pecuniary bribes. Other forms of corruption are: abuse of authority, nepotism, favoritism, fraud, patronage, theft and deceit. Besides, on the award of government contracts or the amount of tax due - bought and sold, but very often access to a public service or the exercise of a right, such as obtaining civil documents, also has to be paid for. In many cases forms of corruptions are intertwined with their consequences.

Corruption has been a part of our politico-administrative heritage, there is little denying the fact that after independence the tentacles of corruption have engulfed the entire society. These are the notable sectors that corruption has seriously invaded which undermine good governance; erode the role of low and hampering economic growth and efforts for poverty reduction in Bangladesh.

From the general people point of view, about half of the people in Bangladesh lives under poverty line where and they are unable to manage their basic needs. They need two meals a day for them and their family. So they do not hesitate to adopt unfair means or offer bribe to fulfill their needs. On the other hand, from the government official point of view, salary structure for the government servants are paid very poor which is barely enough to maintain their families. Although the price of essentials is going up every day their salaries are not increased in proportion to the market price. Besides, there is no arrangement for incentives 
for efficiency or performance. Failing to maintain their families some of them indulge in unfair means. Moreover, there are segments of the government who are by nature corrupted. The absence of honest, courageous leadership to guide the civil servants is the major cause of increase in corruption. Continuance of corruption in a country leads to economic malaise and squandering of public resources, lowers governmental performance, adversely affects general morale in the public service, jeopardizes administrative reform efforts and accountability measures, and perpetuates social and economic inequalities (UN, 1990). Corruption reinforces political instability and underdevelopment (Ouma, 1991). It provides additional cost for citizens for delivery even the most basic government activities. Moreover it can jeopardize the health and safety of citizens. This cost trailing in trust and confidence of people in public institutions.

Corruption is a common unethical behavior of officers in all public service. It may be a petty or may be a grand one. Reducing corruption ethical behavior and code of ethic can be effective as element of anti corruption force. Rose-Ackerman (1998) recommends a two-pronged strategy aimed at increasing the benefits of being honest and the costs of being corrupt, a sensible combination of reward and punishment as the driving force of reforms. Though ethics is sometimes viewed as ineffective and an embarrassment to those who want to get a proper understanding of what is going on. Ethics is also sometimes seen as negative (telling other people what they should not do), impractical (because it is backed only by conscience), and more likely to catch the believing innocent rather than the deliberate offenders. Public service officers have discretionary powers that go beyond the manuals, orders, job descriptions and legal framework of their position and duties, and professional ethics will have to come in as guidelines, in addition to the formal regulations. Increasing privatization and the contracting out of traditional government functions; the devolvement of responsibility, including financial responsibility, within public service organizations; greater pressures for openness and more intensive media scrutiny of the public sector; a greater and growing intensity of lobbying by those anxious to capture government business; and an increased willingness on the part of members of the public to complain when the quality of service is poor - all these have contributed to this increase in awareness of the need to take steps to bolster the ethical basis on which the public service functions. Administrators should therefore seek a broad and solid understanding of ethical theories and traditions, and look for methods for thinking about the ethical dimensions of their decision-making. Considering values and ethics as one of the corner stone's of civil service can be ensured a high level of operations in administration to reduce corruption.

However, the ethical character of an individual may be unpredictable and tenuous, but a weak ethical basis of an individual can be overcome and ethics become meaningful and directional, when a particular setting and structural pressures converge. In addition, reform strategies should take on giving priority on different contexts like economic, legal and political context. Effective strategies need to be tailored to the social environment in which corruption occurs. However, enhancing ethical standard in public servants is a quite new form of curbing corruption in Bangladesh. It does not mean civil servants have no ethics. But the practicing of ethical behavior is limited. This paper is aiming to adding together some new sides on 
enhancing public service ethics curbing way corruption and to identify the grounds of corruption and how ethical standard in this regard can be effective to be civil service system.

\section{Literature Review}

Factors that promote corruption have direct and indirect influenced on civil service system. Corruption is the abuse of public power for private benefit. As a direct factor he noted some reasons such as regulation and authorizations, taxation, spending decisions, provision for goods and services at below markets etc. and indirect factor- quality of bureaucracy, level of public sector wages, penalty systems, institutional controls, transparency of rules, leadership etc. he also discussed about measurement of corruption such as reports, case studies etc. based on surveys. He discussed corruption and growth and how corruption effects on economy. These effects discussed on two side- qualitative and economic results. He also suggested how to fight against corruption such as high level of wages, increasing the penalties for acts of corruption etc. but he did not have any specific suggestion on his paper (Tanzi \&Vito, 1998).

There are a number of number of mechanisms for setting and institutionalizing high standards of ethical conduct integrity of civil servants. On introduction discussion, it is found about expectation of peoples, business leaders and civil society that government will establish higher standers of ethicality and integrity in the civil service. As a result of increasing expectation better focused media attention and public scrutiny, increasing impatience etc. are increased. In this paper three areas has been discussed - Anticipating specific threats to ethics standers and integrity in the public sector, strengthening the ethical competence of civil servants and strengthening mechanisms to support "Professional ethics", developing administrative practices and processes which promote ethical values and integrity. A number of strategies such as effective laws, ethics audit, New Human Resource Management strategies, training and development in the content, ethics code etc. The insufficiency of ethics codes, ethics and corruption Ethics laws, code of ethics and code of conduct discussed very wisely. Transparency, integrity, legitimacy, fairness, responsiveness, efficiency and effectiveness as a implementing effective ethics standards in government and civil service. Maladministration, anticorruption laws and agencies, right to review official decisions, public finance management reforms, integrity testing, responsibilities of citizen etc. are mentioned here as a solutions. But the specification of problem areas is absent (Whitton \& Howard, 2001).

Corruption in developing countries effects on national economies, and the demand and supply sides of corruption. There are different strategies to mitigate corruption including consideration of the cultural dimension of the problem. Understanding the cultural aspect, they argue, helps strengthen enforcement, prevention and state building. After giving an overview of the existing international legal treaties to fight corruption, the authors contend that ensuring compliance with these treaties is important and call for a more rigorous monitoring to determine whether governments live up to their commitments. At the same time, the transnational corporations, which are often a source of corruption and a target for extortion, should be fundamental in an anti- corruption strategy. In conclusion the authors 
underline that corruption inhibits development and economic growth and undermines assistance programs (Heineman \& Heimann, 2006).

\section{Research Method}

This is an explanatory research where survey method has been used for collecting data and information. In this study quantitative approach has been used to examine the existing relationship of the variables and not necessarily to provide any predictive answer to an unsolved issue rather, merely described opinion of the respondents about corruption and ethics.

In this study, field data has been collected from individuals using semi structured questionnaire.The questionnaire was pre-tested before collecting data. The pertinent secondary information was accumulated from the published books, e- books, relevant articles, newspapers, different position papers and relevant websites. Besides, a significant portion of the information has been gathered from literature review.

This study has been conducted covering the area of Bangladesh Telecommunication (BTC) Office at the Taltola, Bandar Bazaar Sylhet and Osmani Medical College, Sylhet in Bangladesh. As population of this study, first-class ranked officers and general people (consumer of public services) have been identified. The total number of respondent or sample size is 50 including 25 officials' respondents and 25 general people who have been selected through random judgment sampling method.

Finally, collected data have been characteristically classified, and then statistical method (e.g. percentage analysis) has been applied on them. Quantitative data have been presented on frequency distribution tables and showed the responses in percentage. The data of the tables are then discussed. Qualitative data have also been analyzed and discussed descriptively in this Study.

\section{Data Presentation and Analysis}

\subsection{Official's Data Analysis}

Table 1. Occupation of the respondents

\begin{tabular}{llll}
\hline Profession & Rank & Number $(\mathrm{N})$ & Percentage \\
\hline Doctor & $1^{\text {st }}$ class & 10 & $40 \%$ \\
Engineer & $1^{\text {st }}$ class & 15 & $60 \%$ \\
Total & & 25 & 100 \\
\hline
\end{tabular}

Source: field data collected from "BTC and Osmani medical college, Sylhet", June 2015.

Table 1 represents that, $40 \%$ of respondent is doctor and $60 \%$ is engineer and both are in $1^{\text {st }}$ class rank. 
Table 2. Reasons of corruption

\begin{tabular}{|c|c|c|c|c|c|c|}
\hline \multirow{3}{*}{$\begin{array}{l}\text { Reasons } \\
\text { Poverty (Lack of money) }\end{array}$} & \multicolumn{2}{|c|}{ Yes } & \multicolumn{2}{|c|}{ No } & \multicolumn{2}{|c|}{ No Comments } \\
\hline & $\mathrm{N}$ & $\%$ & $\mathrm{~N}$ & $\%$ & $\mathrm{~N}$ & $\%$ \\
\hline & 15 & $60 \%$ & 6 & $24 \%$ & 4 & $16 \%$ \\
\hline Greediness & 25 & $100 \%$ & 0 & 0 & 0 & 0 \\
\hline Lack of awareness & 14 & $56 \%$ & 9 & $36 \%$ & 2 & $8 \%$ \\
\hline Insufficient salary & 19 & $76 \%$ & 5 & $20 \%$ & 1 & $4 \%$ \\
\hline Pressure from Higher officials & 19 & $76 \%$ & 4 & $16 \%$ & 2 & $8 \%$ \\
\hline Fear of Transfer & 16 & $64 \%$ & 5 & $20 \%$ & 4 & $16 \%$ \\
\hline Influence of politicians & 15 & $60 \%$ & 5 & $20 \%$ & 5 & $20 \%$ \\
\hline Strong kinship & 11 & $44 \%$ & 12 & $48 \%$ & 2 & $8 \%$ \\
\hline Inequalities & 13 & $52 \%$ & 7 & $28 \%$ & 5 & $20 \%$ \\
\hline Rapid social and economic change & 15 & $60 \%$ & 7 & $28 \%$ & 3 & $12 \%$ \\
\hline Political softness & 12 & $48 \%$ & 7 & $28 \%$ & 6 & $24 \%$ \\
\hline
\end{tabular}

Source: field data collected from "BTC and Osmani medical college, Sylhet “, June 2015

The Table 2 shows that, out of 11 reasons of corruption 10 were identified by the majority of the respondents where Greediness has been found absolute reason of corruption in civil service. Besides, insufficient salary and Pressure from Higher officials have been identified by the second majority $76 \%$ of the respondents. A large number of respondents were found silent about the political reason of corruption.

Table 3. Satisfaction with salary and allowance

\begin{tabular}{lcc}
\hline Pattern of answer & No. of respondents & percentage \\
\hline Yes & 09 & $36 \%$ \\
No & 05 & $20 \%$ \\
Partly & 03 & $12 \%$ \\
No Comments & 08 & 32 \\
Total & 25 & 100 \\
\hline
\end{tabular}

Source: field data collected from "BTCL and Osmani medical college, Sylhet “, June 2015

Table-3 refers that, majority of respondents $36 \%$ are satisfied with their salary and allowance, $20 \%$ of respondent is found not and $12 \%$ is found partly satisfied.

Table 4. Awareness of civil service conduct rules

\begin{tabular}{lll}
\hline Pattern of answer & No. of respondents & Percentage \\
\hline Yes & 22 & $88 \%$ \\
No & 0 & 0 \\
Partly & 3 & $12 \%$ \\
\hline
\end{tabular}

Source: field data collected from "BTC and Osmani medical college, Sylhet “, June 2015 
Table-4 shows that, majority of the respondents $88 \%$ are found that they are aware about their official conduct rules and $12 \%$ of respondents are aware partly about respective conduct rules.

Table 5. Do you follow service of conducting rules

\begin{tabular}{lcc}
\hline Rating scales & N & Percentage \\
\hline Highly & 16 & $64 \%$ \\
Hardly & 2 & $8 \%$ \\
As usually & 7 & $28 \%$ \\
\hline
\end{tabular}

Source: field data collected from "BTC and Osmani medical college, Sylhet “, June 2015

It is apparent from the Table- 5 that, $64 \%$ of the respondents has been following conduct rules highly, $8 \%$ respondents hardly, and $28 \%$ as usual.

Table 6. Lack of awareness about conduct rules increasing corruption

\begin{tabular}{lll}
\hline Pattern of answer & No. of respondents & Percentage \\
\hline Yes & 15 & $60 \%$ \\
No & 2 & $8 \%$ \\
Not sure & 8 & $32 \%$ \\
\hline
\end{tabular}

Source: field data collected from "BTC and Osmani medical college, Sylhet ", June 2015

According to table-6, the most of respondents $60 \%$ gave opinion yes, $8 \%$ no and second highest opinion is $32 \%$ not sure about lack of awareness about rules of conduct can increase corruption.

Table 7. Applications of disciplinary action

\begin{tabular}{lll}
\hline Pattern of answer & No. of respondents & Percentage \\
\hline Yes & 5 & $20 \%$ \\
No & 1 & $4 \%$ \\
Sometimes & 19 & $76 \%$ \\
Source: field data collected from "BTC and Osmani medical college, Sylhet “, June 2015
\end{tabular}

From the Table-7 that, penalty applications appropriately applied or ignored on their office, $20 \%$ of respondents has replied yes, $4 \%$ replied no and majority of respondents $76 \%$ has replied sometimes it is found applications of disciplinary action taken over the civil servant. 
Table 8. Visible corruption or violation of rules in civil service system

\begin{tabular}{|c|c|c|c|c|c|c|}
\hline \multirow[t]{2}{*}{ Types of Corruption } & \multicolumn{2}{|c|}{ Yes } & \multicolumn{2}{|c|}{ No } & \multicolumn{2}{|c|}{ Not Decided } \\
\hline & No. & $\%$ & No. & $\%$ & No. & $\%$ \\
\hline Nepotism & 21 & $84 \%$ & 2 & $8 \%$ & 2 & $8 \%$ \\
\hline Favoritism & 24 & $96 \%$ & 0 & 0 & 1 & $4 \%$ \\
\hline Fraud & 21 & $84 \%$ & 3 & $12 \%$ & 1 & $4 \%$ \\
\hline Bribery & 23 & $92 \%$ & 1 & $4 \%$ & 1 & $4 \%$ \\
\hline Deception & 14 & $56 \%$ & 9 & $36 \%$ & 2 & $8 \%$ \\
\hline Extortion & 17 & $68 \%$ & 3 & $12 \%$ & 5 & $20 \%$ \\
\hline Embezzlement & 15 & $60 \%$ & 7 & $28 \%$ & 3 & $12 \%$ \\
\hline
\end{tabular}

Source: field data collected from "BTC and Osmani medical college, Sylhet “, June 2015.

The Table 8 shows the visible form of corruption, majority of the respondents were agree on listed form of corruption in civil service. Above $90 \%$ the absolute majority of the respondents identified Favoritism and Bribery as a very common form of corruption.

Table 9. The ways to curb corruption

\begin{tabular}{|c|c|c|c|c|c|c|c|c|}
\hline \multirow[t]{2}{*}{ Ways to curb corruption } & \multicolumn{2}{|c|}{$\begin{array}{l}\text { Strictly } \\
\text { Recommend }\end{array}$} & \multicolumn{2}{|c|}{$\begin{array}{l}\text { Moderately } \\
\text { Recommend }\end{array}$} & \multicolumn{2}{|c|}{$\begin{array}{l}\text { If here, will be } \\
\text { positive }\end{array}$} & \multicolumn{2}{|c|}{$\begin{array}{l}\text { Less } \\
\text { Important }\end{array}$} \\
\hline & $\mathrm{N}$ & $\%$ & $\mathrm{~N}$ & $\%$ & $\mathrm{~N}$ & $\%$ & $\mathrm{~N}$ & $\%$ \\
\hline $\begin{array}{l}\text { Stricter enforcement of } \\
\text { conducting rules }\end{array}$ & 23 & $92 \%$ & 2 & $8 \%$ & 0 & 0 & 0 & 0 \\
\hline Awareness building & 17 & $68 \%$ & 6 & $24 \%$ & 1 & $4 \%$ & 1 & $4 \%$ \\
\hline Departmental Campaign & 20 & $80 \%$ & 2 & $8 \%$ & 3 & $12 \%$ & 0 & 0 \\
\hline Ethical standard Monitoring & 21 & $84 \%$ & 4 & $16 \%$ & 0 & 0 & 0 & 0 \\
\hline $\begin{array}{l}\text { Satisfactory salaries of } \\
\text { bureaucrats }\end{array}$ & 20 & $80 \%$ & 4 & $16 \%$ & 0 & 0 & 1 & $4 \%$ \\
\hline $\begin{array}{l}\text { Reducing favoritism and } \\
\text { nepotism }\end{array}$ & 18 & $72 \%$ & 6 & $24 \%$ & 1 & $4 \%$ & 0 & 0 \\
\hline $\begin{array}{l}\text { Recruitment and selection } \\
\text { of right candidates }\end{array}$ & 21 & $84 \%$ & 2 & $8 \%$ & 2 & $8 \%$ & 0 & 0 \\
\hline Transparency in work & 19 & $76 \%$ & 6 & $24 \%$ & 0 & 0 & 0 & 0 \\
\hline $\begin{array}{l}\text { System of Monthly } \\
\text { departmental evaluation }\end{array}$ & 17 & $68 \%$ & 5 & $20 \%$ & 3 & $12 \%$ & 0 & 0 \\
\hline $\begin{array}{l}\text { Provision of incentives to } \\
\text { staffs }\end{array}$ & 18 & $72 \%$ & 5 & $20 \%$ & 2 & $8 \%$ & 0 & 0 \\
\hline Application of penalties & 19 & $76 \%$ & 3 & $12 \%$ & 3 & $12 \%$ & 0 & 0 \\
\hline $\begin{array}{l}\text { New human resource } \\
\text { management }\end{array}$ & 13 & $52 \%$ & 11 & $44 \%$ & 1 & $4 \%$ & 0 & 0 \\
\hline Ethical training & 17 & $68 \%$ & 8 & $32 \%$ & 0 & 0 & 0 & 0 \\
\hline Anti-corruption laws & 21 & $84 \%$ & 3 & $12 \%$ & 0 & 0 & 0 & 0 \\
\hline $\begin{array}{l}\text { Reviewing } \quad \text { official } \\
\text { Decisions }\end{array}$ & 16 & $64 \%$ & 7 & $28 \%$ & 1 & $4 \%$ & 0 & 0 \\
\hline Responsibilities of citizens & 20 & $80 \%$ & 3 & $12 \%$ & 1 & $4 \%$ & 0 & 0 \\
\hline
\end{tabular}

Source: field data collected from "BTC and Osmani medical college, Sylhet ", June 2015 
According to Table 9, Majority of the respondents were found very strict to control through various means. Above $80 \%$ of the respondents identified 7 different criteria to be followed strictly where $92 \%$ of the respondents kept emphasis on stricter enforcement of conducting rules and $84 \%$ of the respondents strictly recommended on Ethical standard Monitoring and Recruitment and selection of right candidates.

Table 10. Exercise of ethics and morale to reduce corruption in near future

\begin{tabular}{lll}
\hline Pattern of answer & No. of respondents & Percentage \\
\hline Agree & 15 & $60 \%$ \\
Disagree & 5 & $20 \%$ \\
Not Sure & 5 & $20 \%$ \\
Total & 205 & 100 \\
\hline
\end{tabular}

Source: field data collected from "BTCL and Osmani medical college, Sylhet “, June 2015.

Table 10 shows that, it is possible to reduce corruption in near future by teaching ethics and morale to younger generation as most of the respondents $60 \%$ said yes, $20 \%$ said no and $20 \%$ said may be possible.

Table 11. Way of increasing ethical behavior to reduce corruption on public service (Here, 1 is for highly emphases and 5 is for less important)

\begin{tabular}{|c|c|c|c|c|c|c|c|c|c|c|}
\hline \multirow{2}{*}{$\begin{array}{l}\text { Ways of Importing Ethical } \\
\text { Standard in Civil Service }\end{array}$} & \multicolumn{2}{|c|}{1} & \multicolumn{2}{|c|}{2} & \multicolumn{2}{|c|}{3} & \multicolumn{2}{|c|}{4} & \multicolumn{2}{|c|}{5} \\
\hline & No. & $\%$ & No. & $\%$ & No. & $\%$ & No. & $\%$ & No. & $\%$ \\
\hline Good behave & 24 & $96 \%$ & 1 & $4 \%$ & 0 & 0 & 0 & 0 & 0 & 0 \\
\hline Honesty & 20 & $80 \%$ & 4 & $16 \%$ & 1 & $4 \%$ & 0 & 0 & 0 & 0 \\
\hline Positive thinking & 18 & $72 \%$ & 6 & $24 \%$ & 1 & $4 \%$ & 0 & 0 & 0 & 0 \\
\hline Accountability & 23 & $92 \%$ & 1 & $4 \%$ & 1 & $4 \%$ & 0 & 0 & 0 & 0 \\
\hline Moral obligations & 21 & $84 \%$ & 2 & $8 \%$ & 2 & $8 \%$ & 0 & 0 & 0 & 0 \\
\hline Selflessness & 13 & $52 \%$ & 9 & $32 \%$ & 1 & $4 \%$ & 0 & 0 & 2 & $8 \%$ \\
\hline Openness & 18 & $72 \%$ & 5 & $20 \%$ & 1 & $4 \%$ & 0 & 0 & 1 & $4 \%$ \\
\hline Readiness to discharge any duty & 16 & $64 \%$ & 5 & $20 \%$ & 0 & 0 & 2 & $8 \%$ & 2 & $8 \%$ \\
\hline
\end{tabular}

Source: field data collected from "BTC and Osmani medical college, Sylhet “, June 2015.

Table 11 shows the possible way to import ethical exercise, above $90 \%$ of the respondents highly emphasized on good behave and accountability as a manner of application of ethics and above $80 \%$ of the respondents kept emphasis on Honesty and Moral obligations. 


\subsection{Public Perceptions Data Analysis}

Table 4.2.1. Main reasons which influence civil servant to do corruption

\begin{tabular}{|c|c|c|c|c|c|c|}
\hline \multirow{2}{*}{ Reasons of Corruptions } & \multicolumn{2}{|c|}{ Yes } & \multicolumn{2}{|c|}{ No } & \multicolumn{2}{|c|}{ No Comments } \\
\hline & No. & $\%$ & No. & $\%$ & No. & $\%$ \\
\hline Poverty (Lack of money) & 21 & $84 \%$ & 4 & $16 \%$ & 0 & 0 \\
\hline Greediness & 21 & $84 \%$ & 2 & $8 \%$ & 2 & $8 \%$ \\
\hline Lack of awareness & 17 & $68 \%$ & 6 & $24 \%$ & 2 & $8 \%$ \\
\hline Insufficient salary & 25 & $100 \%$ & 0 & 0 & 0 & 0 \\
\hline Pressure from Higher officials & 17 & $68 \%$ & 4 & $16 \%$ & 4 & $16 \%$ \\
\hline Fear of Transfer & 10 & $40 \%$ & 14 & $56 \%$ & 1 & $4 \%$ \\
\hline Influence of politicians & 22 & $88 \%$ & 3 & $12 \%$ & 0 & 0 \\
\hline Strong kinship & 14 & $56 \%$ & 9 & $36 \%$ & 2 & $8 \%$ \\
\hline Inequalities & 17 & $68 \%$ & 4 & $16 \%$ & 4 & $16 \%$ \\
\hline Rapid social and economic change & 14 & $56 \%$ & 9 & $36 \%$ & 2 & $8 \%$ \\
\hline Political softness & 14 & $56 \%$ & 9 & $36 \%$ & 2 & $8 \%$ \\
\hline
\end{tabular}

Source: field data, Sylhet Metropolitan Area, June, 2015.

Table 4.2.1 indicates the reasons or the factor that influence civil servant to do corruption, according to percentage of the insufficient salary has been identified by the respondent top of the reasons then political influence (88\%) has been found second top of the reasons behind acting illegal work in civil service.

Table 4.2.2. Do you think current pay scale can help on reducing corruption

\begin{tabular}{lll}
\hline Pattern of answer & No. of respondents & Percentage \\
\hline Yes & 12 & $48 \%$ \\
No & 8 & $32 \%$ \\
Partially & 5 & $20 \%$ \\
\hline
\end{tabular}

Source: field data, Sylhet Metropolitan Area, June, 2015

Table 4.2.2 shows that, majority of respondents $48 \%$ mentioned current pay scale can ameliorate corruption situation in civil service, and $32 \%$ of the respondents did not agree and the rest $20 \%$ of the respondents partially it will have positive impact.

Table 4.2.3. Application of strict Penalty can reduce corruption

\begin{tabular}{lll}
\hline Pattern of answer & No. of respondents & Percentage \\
\hline Yes & 15 & $60 \%$ \\
No & 2 & $8 \%$ \\
May be & 8 & $32 \%$ \\
\hline
\end{tabular}

Source: field data, Sylhet Metropolitan Area, June, 2015. 
According to Table $4.2 .3,60 \%$ of respondents mentioned positive about strict application of penalty action in civil service, and $32 \%$ of respondents were found confused on it and the rest of respondents did not agree with it.

Table 4.2.4. Kind of corruption or violation of rules is visible in civil service system

\begin{tabular}{|c|c|c|c|c|c|c|}
\hline \multirow{2}{*}{ Types of Corruptions } & \multicolumn{2}{|c|}{ Yes } & \multicolumn{2}{|c|}{ No } & \multicolumn{2}{|c|}{ Not Decided } \\
\hline & No. & $\%$ & No. & $\%$ & No. & $\%$ \\
\hline Nepotism & 25 & $100 \%$ & 0 & 0 & 0 & 0 \\
\hline Favoritism & 24 & $96 \%$ & 1 & $4 \%$ & 0 & 0 \\
\hline Fraud & 17 & $68 \%$ & 5 & $20 \%$ & 3 & $12 \%$ \\
\hline Bribery & 21 & $84 \%$ & 2 & $8 \%$ & 2 & $8 \%$ \\
\hline Theft and deceit & 15 & $60 \%$ & 7 & $28 \%$ & 3 & $12 \%$ \\
\hline Extortion & 15 & $60 \%$ & 5 & $20 \%$ & 5 & $20 \%$ \\
\hline Embezzlement & 17 & $68 \%$ & 3 & $12 \%$ & 5 & $20 \%$ \\
\hline
\end{tabular}

Source: field data, Sylhet Metropolitan Area, June, 2015.

Nepotism has been found at the top among all the corruption according to opinion of the all respondents. Favoritism has been identified as the second top (96\%) form of corruption in civil service (Table: 4.2 .4 ).

Table 4.2.5. The ways to curb corruption

\begin{tabular}{|c|c|c|c|c|c|c|c|c|}
\hline \multirow[t]{2}{*}{ Ways to curb corruption } & \multicolumn{2}{|c|}{$\begin{array}{l}\text { Strictly } \\
\text { Recommen } \\
\text { d }\end{array}$} & \multicolumn{2}{|c|}{$\begin{array}{l}\text { Moderately } \\
\text { Recommen } \\
\text { d }\end{array}$} & \multicolumn{2}{|c|}{$\begin{array}{l}\text { If here, will } \\
\text { be positive }\end{array}$} & \multicolumn{2}{|c|}{$\begin{array}{l}\text { Less } \\
\text { Important }\end{array}$} \\
\hline & No. & $\%$ & No. & $\%$ & No. & $\%$ & No. & $\%$ \\
\hline Stricter enforcement of conducting rules & 21 & $84 \%$ & 2 & $8 \%$ & 1 & $4 \%$ & 1 & $4 \%$ \\
\hline Awareness building & 16 & $64 \%$ & 5 & $20 \%$ & 4 & $16 \%$ & 0 & 0 \\
\hline Departmental Campaign & 8 & $32 \%$ & 9 & $36 \%$ & 5 & $20 \%$ & 3 & $12 \%$ \\
\hline Ethical standard Monitoring & 12 & $48 \%$ & 9 & $36 \%$ & 4 & $16 \%$ & 0 & 0 \\
\hline Satisfactory salaries of bureaucrats & 22 & $88 \%$ & 1 & $4 \%$ & 1 & $4 \%$ & 1 & $4 \%$ \\
\hline Reducing favoritism and nepotism & 14 & $56 \%$ & 8 & $32 \%$ & 3 & $12 \%$ & 0 & $\mathrm{O}$ \\
\hline Recruitment and selection of right candidates & 20 & $80 \%$ & 2 & $8 \%$ & 1 & $4 \%$ & 2 & $8 \%$ \\
\hline Transparency in work & 16 & $64 \%$ & 6 & $24 \%$ & 1 & $4 \%$ & 2 & $8 \%$ \\
\hline System of Monthly departmental evaluation & 11 & $44 \%$ & 10 & $40 \%$ & 3 & $12 \%$ & 0 & 0 \\
\hline Provision of incentives to staffs & 10 & $40 \%$ & 8 & $32 \%$ & 5 & $20 \%$ & 1 & $4 \%$ \\
\hline Application of penalties & 18 & $72 \%$ & 4 & $16 \%$ & 3 & $12 \%$ & 0 & 0 \\
\hline New human resource management & 12 & $48 \%$ & 5 & $20 \%$ & 7 & $28 \%$ & 1 & $4 \%$ \\
\hline Ethical training & 11 & $44 \%$ & 5 & $20 \%$ & 7 & $28 \%$ & 1 & $4 \%$ \\
\hline Anti-corruption laws & 19 & $76 \%$ & 4 & $16 \%$ & 2 & $8 \%$ & 0 & 0 \\
\hline Reviewing official Decisions & 9 & $36 \%$ & 11 & $44 \%$ & 4 & $16 \%$ & 1 & $4 \%$ \\
\hline Responsibilities of citizens & 12 & $48 \%$ & 7 & $28 \%$ & 4 & $16 \%$ & 2 & $8 \%$ \\
\hline
\end{tabular}

Source: field data, Sylhet Metropolitan Area, June, 2015. 
According to the Table 4.2.5, general people have identified different ways to control corruption from the given list. Stricter enforcement of conducting rules, satisfactory salaries of bureaucrats, and recruitment and selection of right candidates have been identified above the $80 \%$ of the respondents.

\section{Findings and Discussion}

From the observation it has been found the entire government official were from the class one official that may indicate biasness of the responses because as they are from the same class might have been same thinking about their profession. Class has the same feelings about the duties and responsibilities, therefore different class may bring different arena of corruption in government service.

A considerable scientific debate has been existing around us on how to make the public sector function in the best way, its possible answer are is needed to achieve economic development, political accountability, poverty eradication and achievement of other objectives. But how this could be if government sector involves and submerge in corruption? It's ineffectual if the factors of corruption are available in civil service. Civil servants are found involved in various ways of corruption and having or showing a selfish desire for wealth and possessions are the top most reason besides not receiving or offering much pay to the government officials are the source of corruption. Corruption is usually connected with activities of state and monopoly and discretionary power of the government. Political pressure and influence of the higher official may be the factor that generates corruption with the misuse discretionary power.

The values that are enshrined in civil service must also be those that guide civil servants in all their actions: fundamental human rights, social justice, the dignity and worth of the human person and respect for the equal rights of men and women. Civil service conduct rules can compose these in a way that they must be obeying to serve the people. They must be aware of their respective departmental rules and regulation as well as overall government regulations and is has been found they are obeyed in Bangladesh civil service. Government officials are following it by their best as it is known to all absence of disciple can leads rampant corruption.

Corruption takes many forms. These forms are; Nepotism, Favoritism means acceptance of money and other rewards for awarding contracts, Fraud; Bribery means the violation of procedures to advance personal interests, and overlooking illegal activities. These categories of corruptions are visible in small or broad spectrum in civil service. The general people and the officials have the same perceptions on it. In order to reduce corruption drastically, a number of fundamental changes must be brought about; stricter enforcement of conducting rules, Departmental Campaign against corruptions and enhancing ethics, ascendance of universalistic norms and satisfactory salaries.

The government officials that are the carriers of the duties and obligations to provide us with our legal and moral rights, freedoms and welfare are usually understood as the state or the public

Sector. The public sector is composed of two core elements; at the political level there are the 
political institutions where policies are formulated and the (major) decisions are made, and at the administrative level there is the public sector administration, which is in charge of implementing these policies and decisions. This implementing level is also called the civil service or state administration or bureaucracy. Ethics in public sector has long been a divisive area of study in the professions as it varies profession to profession and country to country. Many people believe that ethics is too effective to be of real importance in government service. Traditionally, good behave are the foundation of ethical standard and that is the moral philosophy of life. Importation of moral obligations what makes actions right and wrong can bring self judgment in government official's manner. In ethics and governance, accountability is answerability, blameworthiness, liability, and the expectation of account-giving and in ethics openness means is an overarching concept or philosophy that is characterized by an emphasis on transparency and free, unrestricted access to knowledge and information, as well as collaborative or cooperative management and decision-making rather than a central authority.

No matter how big and what role the state is playing, both politicians and civil servants have discretionary powers; they make decisions that affect a lot of people. Therefore, these decisions ought to be based on some form of ethics.

\section{Conclusion and Recommendation}

All parts of society must share the responsibility for containing corruption because all are willing or unwilling participants. But the government is responsible for dealing with civil servants who engage in extortion and bribery. The causes of corruption are as varied as the phenomenon itself. Corruption results from the presence of a number of factors. Responsibility alone does not lie with the government for controlling corruption. Rather government leaders, politicians and bureaucrats, must provide the political will to address all forms of corruption. The prevalence of systematic corruption in Bangladesh society can be explained due to a number of factors. Lack of political will, lack of organized movement by civil society for a change in the status quo, and presence of a change-resistant institutional bureaucracy, lack of ethics in public life, absence of independence of judiciary and media, have all contributed in varying degrees to the continuance of large-scale and systematic corruption in all spheres of Bangladeshi society. To control this spreading vice we may adopt some measures. Governments need to introduce appropriate legislation to reduce corruption and provide whatever means are necessary to ensure that appropriate steps are taken to build systems of integrity and rule of law. The public sector is that portion of society controlled by national, state or provincial, and local governments (Islam, F.2015). Public servant is an authority in the service of the rights of citizens and the law in general. The civil service corps member shall treat his work as a public service; always bear in mind the common good of the people of the Republic and democratic system. The civil service corps member shall be impartial in the execution of their assignments and duties and ensure equal treatment to all the parties involved, without surrendering to any pressure. There must be practice of ethical behavior lesson in our everyday life and professon. A code of conduct in profesion is very important to redice corruption and enhancing ehics in service. It is a set of rules outlining the responsibilities of - or proper practices for - an individual or organization. This ethical 
standard setting is an important guide to making decisions on complicated ethical issues, and they can provide the basis for an environment where citizens are aware of the basic standards of behavior to be expected from public sector employees. The general principles of the code ethics means that the public official should carry out his or her duties in accordance with the law, and with those lawful instructions and ethical standards which relate to his or her functions, and that the public official should act ina politically neutral manner and should not attempt to frustrate the lawful policies, decisions or actions of the public authorities. Besides, ensuring transparency in public service can be very effective to as it is the principle of public access to information, accessible to all relevant stakeholders, in a timely and reliable way. Effective use of public revenues is strongly linked to accountability, because it is a prerequisite for accountable government. In order to ensure ethical standard to ameliorate malfunction in public service a number of measure can be effective ; Public servants need to know the basic principles and standards they are expected to apply to their work and where the boundaries of acceptable behavior lie. Ethical standards should be reflected in the legal framework. Ethical guidance should be available to public servants through professional socialization; it should contribute to the development of the necessary judgment and skills to enable public servants to apply ethical principles. Public servants need to know what their rights and obligations are in terms of exposing actual or suspected wrongdoing within the public service. These should include clear rules and procedures for officials to follow, and a formal chain of responsibility. Political leaders are responsible for maintaining a high standard of propriety in the discharge of their official duties. There should be clear guidelines for interaction between the public and private sectors. Public service employment conditions, such as career prospects, personal development, adequate remuneration and human resource management policies should create an environment conducive to ethical behavior.

\section{References}

Burrell, G., \& Gareth, M. (1988). Sociological Paradigms and Organizational Analysis. London: Heinemann.

Collier, M. W. (2002) Explaining corruption: an institutional choice approach. Crime, Law and Social Change, 38(1), 1-32. http://dx.doi.org/10.1023/A:1019802614530

Elazar, D. (1972). American Federalism. New York: Thomas Crowell.

Heidenheimer, A. J. (1978). Political Corruption: Reading in Comparative Analysis. New York: Holt, Reinhart and Winston. Inc.

Heineman, B. W., \& Fritz, H. (2006). The Long War against Corruption. Retrieved from https:/www.foreignaffairs.com/articles/2006-05-01/long-war-against-corruption

Heywood, P. (1997). Political Corruption: Problems and Perspectives. Political Studies, 45(3), 417-435. http://dx.doi.org/10.1111/1467-9248.00089

Islam, F. (2015). New Public Management (NPM): A dominating paradigm in public sectors. African Journal of Political Science and International Relations, 9(4), 141-152. 
Myrdal, G. (1968). Corruption: Its causes and effects. In G. Myrdal (Ed.), Asian drama: An enquiry into the poverty of nations (Vol. II). New York: The Twentieth Century Fund Newbury Park, CA: Sage

Ouma, O. A. (1991). Corruption in Public Policy and its Impact on Development: The Case of Uganda since 1979. PAD, 11(5), 473-489. http://dx.doi.org/10.1002/pad.4230110505

Rose-Ackerman. (1998). Six Strategies to Fight Corruption. Retrieved from http://blogs.worldbank.org/futuredevelopment/six-strategies-fight-corruption

Tanzi, V. (1998). Corruption Around The World: Causes, Consequences, Scope and curses. International Monetary Fund, Fiscal Affairs Department.

Tilman, R. O. (1968). Emergence of Black-Market Bureaucracy: Administration, Development, and Corruption in the New States. Public Administration Review, 28(5), 437-444. http://dx.doi.org/10.2307/973760

Tobin, I. M., \& Hyunkuk, L. (2012). Can Public Service Motivation Reduce Corruption? Evidence from Korean Public Servants. Paper presented at the The International Public Management Network Conference, Hawaii.

United Nations. (1990). Corruption in Government.Report of an Interregional Seminar held in The Hague, The Netherlands on December 11-15. New York: The United Nations

Whitton, H. (February 2001). Implementing Effective ethics standards In Government and the Civil Service. Transparency International.

\section{Notes}

Note 1. The World Bank, Helping Countries Combat Corruption: The Role of the World Bank, Poverty Reduction and Economic Management Network, September 1997. See pages 19-20 on definitions of corruption.

\section{Copyright Disclaimer}

Copyright for this article is retained by the author(s), with first publication rights granted to the journal.

This is an open-access article distributed under the terms and conditions of the Creative Commons Attribution license (http://creativecommons.org/licenses/by/3.0/). 